\title{
Od Redakcji
}

Kolejny, 12. tom „Z Badań nad Książką i Księgozbiorami Historycznymi” zawiera tradycyjnie teksty z zakresu bibliologii historycznej. Jego główna część składa się z 18 artykułów i dwóch komunikatów poświęconych dziejom książki i bibliotek od średniowiecza po drugą połowę XX w., zarówno w Polsce jak i za granicą. Całość uzupełnia tradycyjnie dział recenzji i notek recenzyjnych oraz Kronika opisująca konferencje i sesje naukowe zorganizowane w 2018 r., które mogą zainteresować historyków książki i bibliotek oraz medioznawców.

Zamykając ten wątek tradycyjnie serdecznie dziękujemy Autorom za interesujące teksty, Recenzentom za to, że wsparli ich swoimi uwagami, a także okazali nieocenioną pomoc Redakcji oraz członkom Rady Redakcyjnej za współpracę, która pozwoliła przygotować możliwie najlepiej wydawnictwo do jego publikacji elektronicznej i do druku.

Chcemy też poinformować naszych Czytelników, iż w przygotowaniu jest tom specjalny „Z Badań nad Książką i Księgozbiorami Historycznymi” poświęcony przede wszystkim roli książki i jej instytucji w tworzeniu i zachowaniu dziedzictwa kulturowego II Rzeczypospolitej. Nasze zaproszenie dla Szanownych Autorów do udziału w kreowaniu tej publikacji pozostaje aktualne - teksty można przesyłać do końca lutego 2019 r.

Rok 2018 był dla Redakcji okresem kontynuacji prac nad ulepszeniem wersji elektronicznej periodyku i jego włączeniem do platformy internetowej wdrażanej przez Wydział Dziennikarstwa, Informacji i Bibliologii Uniwersytetu Warszawskiego. Dlatego w bieżącym tomie „Z Badań nad Książką i Księgozbiorami Historycznymi" i na stronie internetowej czasopisma poczyniliśmy kolejne zmiany przybliżające go do standardów obowiązujących w edytorstwie periodyków elektronicznych. Do ważniejszych należy przypisanie artykułom cyfrowego identyfikatora dokumentu elektronicznego (DOI digital object identifier) oraz obligatoryjny wymóg wobec autorów podawania identyfikatora ORCID (Open Researcher and Contributor ID), bez którego nie możemy przyjmować tekstów do ewentualnej publikacji. Niezależnie od planowanych i już wdrożonych zmian pragniemy zapewnić wszystkich zainteresowanych, że „Z Badań nad Książką i Księgozbiorami Historycznymi” będzie ukazywało się także w formie tradycyjnej.

Jacek Puchalski 